Proceedings of the 3rd International Congress APMAS2013, April 24-28, 2013, Antalya, Turkey

\title{
The Spark Plasma Sintering of Silicon Carbide Ceramics Using Alumina
}

\author{
M.D. Unlu, G. Goller, O. Yucel And F.C. SAhin \\ Istanbul Technical University, Metallurgical and Materials Engineering Department \\ 34469 Maslak, Istanbul, Turkey
}

\begin{abstract}
$\mathrm{SiC}$ ceramics were fabricated by spark plasma sintering technique with the use of $\mathrm{Al}_{2} \mathrm{O}_{3}$ additive. The sintering process was carried out at three different temperatures in the range of $1700-1800^{\circ} \mathrm{C}$ applying two different pressures 40 and $80 \mathrm{MPa}$ under vacuum atmosphere. The effect of additive, different temperatures and pressures on densification behaviour, density, Vickers hardness, fracture toughness, and microstructure were examined. The hardness and fracture toughness of the samples were evaluated by the Vickers indentation technique. Microstructure of spark plasma sintered $\mathrm{SiC}$ samples were characterized by using scanning electron microscopy technique. The highest value of fracture toughness $5.9 \pm 0.2 \mathrm{MPa} \mathrm{m}^{1 / 2}$ was achieved with the addition of 5 vol.\% $\mathrm{Al}_{2} \mathrm{O}_{3}$.
\end{abstract}

DOI: 10.12693/APhysPolA.125.257

PACS: 81.20.Ev, 81.05.Je

\section{Introduction}

Silicon carbide is a very interesting ceramic material due to its properties like high hardness, low bulk density, high oxidation resistance, excellent mechanical strength, and thermal stability which made $\mathrm{SiC}$ useful for a wide range of industrial application $[1,2]$. One of the greatest drawbacks in the manufacture of $\mathrm{SiC}$ is the difficulty in sintering dense samples without the use of additives. This is because the covalent nature of the $\mathrm{Si}-\mathrm{C}$ bonds and the low self-diffusion coefficients require very high sintering temperatures and pressures [3]. Depending on the kinds of doped sintering aids, $\mathrm{SiC}$ may be densified to high density by either a solid-state or liquid phase sintering mechanisms. Sintering of $\mathrm{SiC}$ with the aid of $\mathrm{B}$ and $\mathrm{C}$ is regarded to take place by solid-state diffusion process. This technology requires sintering temperatures of more than $2100^{\circ} \mathrm{C}$ and easily results in exaggerated grain growth, which is hazardous to the mechanical properties [4].

In the recent years, liquid phase silicon carbide has been developed as a material with a higher fracture toughness than the solid phase sintered $\mathrm{SiC}$ but with a similar hardness. The use of yttria or other rare earth oxides and $\mathrm{Al}_{2} \mathrm{O}_{3}$ or AlN as sintering additives, which form together with the $\mathrm{SiO}_{2}$ existing on the surface of the starting SiC-powder, a liquid phase during the sintering, promotes the densification and microstructural development $[5,6]$. Liquid phase sintering allows densification of $\mathrm{SiC}$ at temperatures close to $1900^{\circ} \mathrm{C}$ without the use of external pressures. These temperatures are much lower than the close to $2200^{\circ} \mathrm{C}$ required by the conventional solid-state sintering [3]. The liquid-phase sintered $\mathrm{SiC}$ ceramics have high fracture toughness compared with solid phase sintered $\mathrm{SiC}$, because the elongated grains can form during liquid-phase sintering [7]. However, a major problem associated with sintering of silicon carbide in the presence of oxide additives is the reaction between the silicon carbide and the oxides. The major weight loss in the $\mathrm{SiC}-\mathrm{Al}_{2} \mathrm{O}_{3}-\mathrm{Y}_{2} \mathrm{O}_{3}$ system during sintering is a result of the formation of gaseous $\mathrm{CO}, \mathrm{SiO}, \mathrm{Al}_{2} \mathrm{O}$, and $\mathrm{Al}[5]$.
The objective of this work is to rapidly densify $\mathrm{SiC}$ powders with the use of $\mathrm{Al}_{2} \mathrm{O}_{3}$ additive and investigate the influence of the additive and the spark plasma sintering (SPS) temperature and pressure on the microstructure, densification behaviour and some mechanical properties.

\section{Experimental procedure}

The samples were prepared starting from $\alpha$-SiC powder (UF-10 H.C. Starck, Germany) with its average particle size of $0.7 \mu \mathrm{m}$ and $5 \mathrm{vol} . \% \alpha-\mathrm{Al}_{2} \mathrm{O}_{3}$ (Inframat Advanced Materials) with its average particle size of $100 \mathrm{~nm}$ as additive. The oxygen content in the starting powder was $0.74 \mathrm{wt} \%$. The powders were wet-mixed in ethanol with $\mathrm{SiC}$ balls in a plastic bottle to ensure homogeneity. Then, the slurry was dried at $100^{\circ} \mathrm{C}$ for $24 \mathrm{~h}$ in an oven and ethanol was removed. After drying and sieving to $150 \mu \mathrm{m}$, a graphite die with a $50 \mathrm{~mm}$ inner diameter was filled with the powder, and they were sintered by the SPS technique (SPS-7.40MK-VII, SPS Syntex Inc.) under a vacuum atmosphere by applying 40 and $80 \mathrm{MPa}$ of pressure. The sintering process was carried out at three different temperatures in the range of $1700-1800{ }^{\circ} \mathrm{C}$ with a heating rate of $100{ }^{\circ} \mathrm{C} / \mathrm{min}$ under a vacuum atmosphere.

In order to compare the densification behaviour of $\mathrm{SiC}-\mathrm{Al}_{2} \mathrm{O}_{3}$ ceramics with monolithic $\mathrm{SiC}$ ceramics, the $\alpha$-SiC powder (UF-10 H.C. Starck, Germany) was prepared with the same powder preparation procedure and spark plasma sintered at four different temperatures in the range of $1800-1950^{\circ} \mathrm{C}$ under two different pressures, $40 \mathrm{MPa}$ and $80 \mathrm{MPa}$ with a heating rate of $100^{\circ} \mathrm{C} / \mathrm{min}$ under a vacuum atmosphere without using sintering additives.

The temperature of the SPS process was measured with an optical pyrometer that was focused on the surface of the die. The current was controlled manually. Linear shrinkage of the specimens during the SPS process was continuously monitored by displacement of the punch rods. After soaking the powder at a desired temperature for $5 \mathrm{~min}$, the applied current was reduced, the pressure was released, and the specimen was cooled down 
to room temperature. The densified samples were in the form of disks $50 \mathrm{~mm}$ in diameter and $5 \mathrm{~mm}$ thick and sand-blasted to remove the graphitic sheet.

The densities of the sintered bodies were measured by Archimedes' method in distilled water. Samples were polished by using diamond polishing solution. The hardness and fracture toughness $\left(K_{\mathrm{IC}}\right)$ of the samples were evaluated by the Vickers indentation technique at a load of $49 \mathrm{~N}$ (Struers, Duramin A300). Fracture toughness values were determined by measuring the half-length of a crack formed around the indentations and calculated by using the following equation:

$$
K_{\mathrm{IC}}=0.016(E / H)^{1 / 2} \times\left(P / C^{3 / 2}\right),
$$

where $K_{\mathrm{IC}}$ is the fracture toughness, $E$ is the elastic modulus, $H$ is the hardness, $P$ is the load and $2 C$ is the full crack length produced by the Vickers $\mathrm{HV}$ indentation. The hardness and fracture toughness data were averaged over ten measurements. Microstructural investigation was performed by a scanning electron microscope (SEM, model JSM 7000F, JEOL, Japan) on a fracture surface.

\section{Results and discussion}

The densification of specimens during the SPS process was evaluated by the displacement of punch rods due to the shrinkage of samples. Figure 1 shows the effect of the sintering pressure and temperature on the displacement of the monolithic $\mathrm{SiC}$ ceramics SPSed at $1800^{\circ} \mathrm{C}$ under a pressure of $40 \mathrm{MPa}$ (Fig. 1a), SPSed at $1950^{\circ} \mathrm{C}$ under a pressure of $80 \mathrm{MPa}$ (Fig. 1b), and $\mathrm{Al}_{2} \mathrm{O}_{3}$ added $\mathrm{SiC}$ ceramics SPSed at $1800^{\circ} \mathrm{C}$ under a pressure of $40 \mathrm{MPa}$ (Fig. 1c) under a pressure of $80 \mathrm{MPa}$ (Fig. 1d) with a 5 min soaking time under a vacuum atmosphere.
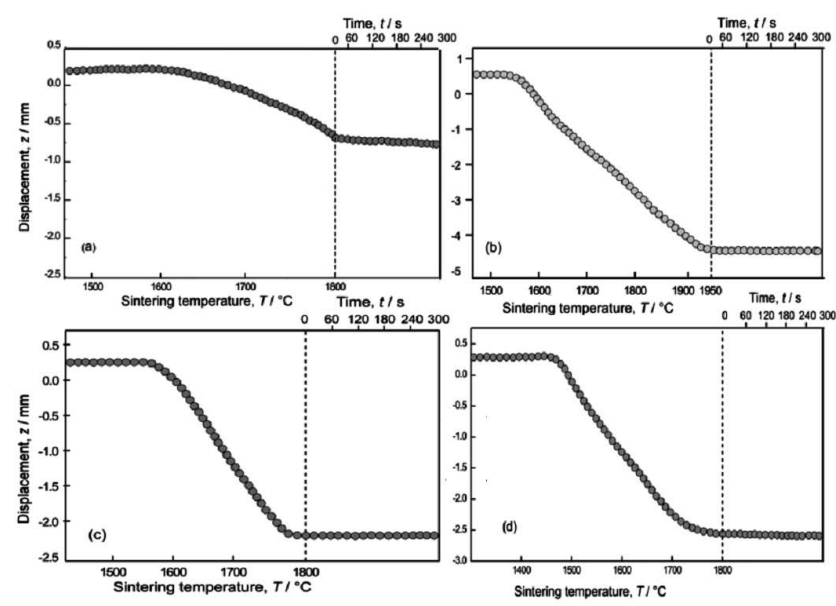

Fig. 1. Effect of sintering temperature on the displacement of the $\mathrm{SiC}$ ceramics (a) SPSed at $1800^{\circ} \mathrm{C}$ under a pressure of $40 \mathrm{MPa}$, (b) SPSed at $1950{ }^{\circ} \mathrm{C}$ under a pressure of $80 \mathrm{MPa}$, (c) $\mathrm{SiC}+5$ vol. $\% \mathrm{Al}_{2} \mathrm{O}_{3}$ SPSed at $1800{ }^{\circ} \mathrm{C}$ under a pressure of $40 \mathrm{MPa},(\mathrm{d}) \mathrm{SiC}+5$ vol.\% $\mathrm{Al}_{2} \mathrm{O}_{3}$ SPSed at $1800{ }^{\circ} \mathrm{C}$ under a pressure of $80 \mathrm{MPa}$.

The monolithic $\mathrm{SiC}$ ceramic heated to $1800^{\circ} \mathrm{C}$ while applying $40 \mathrm{MPa}$ of pressure began to shrink at $1637^{\circ} \mathrm{C}$, and shrinking was completed at $1800^{\circ} \mathrm{C}$, whereas the specimen SPSed at $1950^{\circ} \mathrm{C}$ while applying $80 \mathrm{MPa}$ of pressure started to shrink at $1530^{\circ} \mathrm{C}$, and shrinking was completed at $1950^{\circ} \mathrm{C}$. An increase in the applied SPS temperature and pressure decreased the starting temperatures of shrinkage. Moreover, the higher the applied pressure during SPS treatment, the higher the densification process. For the sample containing 5 vol.\% $\mathrm{Al}_{2} \mathrm{O}_{3}$ additive and SPSed at $1800{ }^{\circ} \mathrm{C}$ under a pressure of $40 \mathrm{MPa}$ the shrinkage started at $1540^{\circ} \mathrm{C}$. An increase in the applied pressure from 40 to $80 \mathrm{MPa}$ decreased the starting temperature of shrinkage to $1490^{\circ} \mathrm{C}$. The addition of 5 vol. $\% \mathrm{Al}_{2} \mathrm{O}_{3}$ resulted in a decrease in the shrinkage starting temperature from $1637^{\circ} \mathrm{C}$ to $1540^{\circ} \mathrm{C}$ for the sample SPSed at $1800^{\circ} \mathrm{C}$ under a pressure of $40 \mathrm{MPa}$.

For the monolithic $\mathrm{SiC}$ samples, as the sintering temperature and pressure were increased from $1800^{\circ} \mathrm{C}$ to $1950{ }^{\circ} \mathrm{C}$ and $40 \mathrm{MPa}$ to $80 \mathrm{MPa}$, respectively, the relative density of the bulk compact increased from $87 \%$ to $99.7 \%$ due to the pore elimination and expedited rearrangement of the grains. Higher sintering temperatures resulted in higher densification rates of spark plasma sintered $\mathrm{SiC}$ ceramics, which led to a decrease in porosity. The highest relative density value obtained was approximately $99.7 \%$ for the sample SPSed at $1950^{\circ} \mathrm{C}$ while applying $80 \mathrm{MPa}$ of pressure, revealing that the sintering pressure has a significant influence on the relative density of the $\mathrm{SiC}$ ceramics in case of the solid state sintering. The use of $\mathrm{Al}_{2} \mathrm{O}_{3}$ as a sintering additive, which reacts with the $\mathrm{SiO}_{2}$ existing on the surface of the starting $\mathrm{SiC}$-powder, forms a liquid phase during the sintering process and the liquid promotes the densification. The addition of 5 vol. $\% \mathrm{Al}_{2} \mathrm{O}_{3}$ resulted in an increase in relative density from $87 \%$ to $97.7 \%$ for the samples SPSed at $1800^{\circ} \mathrm{C}$ under a pressure of $40 \mathrm{MPa}$. This result is in a good correlation with the liquid phase sintering which enhances the densification.

Figure 2 shows the SEM images of the fracture surfaces of both monolithic and the samples containing 5 vol.\% $\mathrm{Al}_{2} \mathrm{O}_{3}$ additive. Both liquid phase and solid state sintering mechanisms can be observed under the same SPS conditions (Fig. 2a-c). Homogeneous and fine-grained microstructures were obtained by liquid phase sintering (Fig. 2c,d).

Additionally, a slight increase in grain size can be observed in the samples SPSed at relatively higher temperatures (Fig. 2b). More pores were investigated on the fracture surface of the ceramic SPSed at $1800{ }^{\circ} \mathrm{C}$ while applying $40 \mathrm{MPa}$ of pressure. Correspondingly, the relative density of the ceramic SPSed with these parameters is only $87.2 \%$. Few pores were detected on the fracture surface of the ceramic SPSed at $1950^{\circ} \mathrm{C}$ while applying $80 \mathrm{MPa}$ pressure; increasing the sintering temperature and pressure results in a decrease in porosity, producing a sample with almost the full density (99.7\%).

The Vickers hardness value of $10.2 \mathrm{GPa}$ was attained in the sample spark plasma sintered at $1800^{\circ} \mathrm{C}$ under an applied pressure of $40 \mathrm{MPa}$; however, increasing the sinter- 


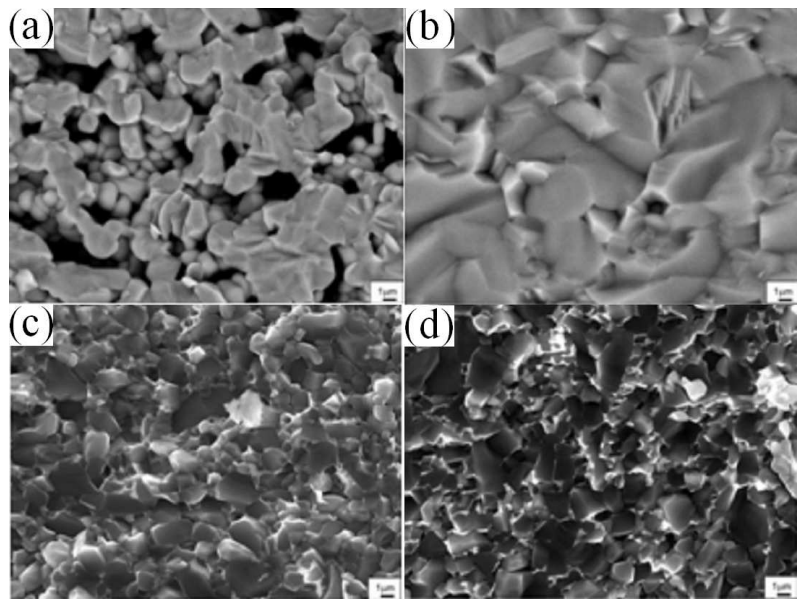

Fig. 2. SEM images of fracture surfaces of SiC ceramics (a) SPSed at $1800^{\circ} \mathrm{C}$ under a pressure of $40 \mathrm{MPa}$, (b) SPSed at $1950{ }^{\circ} \mathrm{C}$ under a pressure of $80 \mathrm{MPa}$, (c) $\mathrm{SiC}+5$ vol. $\% \mathrm{Al}_{2} \mathrm{O}_{3}$ SPSed at $1800{ }^{\circ} \mathrm{C}$ under a pressure of $40 \mathrm{MPa}$, (d) $\mathrm{SiC}+5$ vol. $\% \mathrm{Al}_{2} \mathrm{O}_{3}$ SPSed at $1800{ }^{\circ} \mathrm{C}$ under a pressure of $80 \mathrm{MPa}$.

ing temperature to $1950^{\circ} \mathrm{C}$ caused it to reach $31.9 \mathrm{GPa}$. It was concluded that a higher sintering temperature and pressure led to an increase in the Vickers hardness of the $\mathrm{SiC}$ ceramics due to accelerated densification results in the value of the relative density. The addition of $5 \mathrm{vol} . \% \mathrm{Al}_{2} \mathrm{O}_{3}$ increased the Vickers hardness from 10.2 to $26.8 \mathrm{GPa}$ for the samples SPSed at $1800^{\circ} \mathrm{C}$ while applying $40 \mathrm{MPa}$ of pressure (Table).

TABLE

Relative density, Vickers hardness and fracture toughness values of the SPSed ceramics.

\begin{tabular}{c|c|c|c|c}
\hline \hline Samples & $\begin{array}{c}\text { SPS } \\
\text { parameters } \\
{\left[{ }^{\circ} \mathrm{C}, \mathrm{MPa}, \mathrm{min}\right]}\end{array}$ & $\begin{array}{c}\text { Relative } \\
\text { density } \\
{[\%]}\end{array}$ & $\begin{array}{c}\text { Vickers } \\
\text { hardness } \\
{[\mathrm{GPa}]}\end{array}$ & $\begin{array}{c}\text { Fracture } \\
\text { toughness } \\
\text { [MPa m }\end{array}{ }^{1 / 2}$ ] \\
\hline & $1700,40,5$ & 97.7 & 26.4 & $4.6 \pm 0.2$ \\
$\mathrm{SiC}+5$ vol.\% & $1750,40,5$ & 97.7 & 26.7 & $4.7 \pm 0.3$ \\
$\mathrm{Al}_{2} \mathrm{O}_{3}$ & $1800,40,5$ & 97.8 & 26.9 & $5.8 \pm 0.5$ \\
& $1700,80,5$ & 97.5 & 26.2 & $5.7 \pm 0.2$ \\
& $1750,80,5$ & 98.2 & 28.6 & $5.5 \pm 0.4$ \\
\hline monolithic & $1800,80,5$ & 98.3 & 28.9 & $5.9 \pm 0.2$ \\
$\mathrm{SiC}$ & $1950,80,5$ & 87.2 & 10.2 & - \\
& & 99.7 & 31.9 & $3.6 \pm 0.3$
\end{tabular}

The fracture toughness that could be achieved, $3.6 \pm 0.3 \mathrm{MPa} \mathrm{m}^{1 / 2}$, was with the sample SPSed at $1950{ }^{\circ} \mathrm{C}$ while applying $80 \mathrm{MPa}$ of pressure. For the monolithic SiC ceramic SPSed at $1800^{\circ} \mathrm{C}$ while applying $40 \mathrm{MPa}$ of pressure, fracture toughness cannot be determined because of its lower density. The addition of 5 vol. $\% \mathrm{Al}_{2} \mathrm{O}_{3}$ increased the fracture toughness value to $5.8 \pm 0.5 \mathrm{MPa} \mathrm{m}^{1 / 2}$ for the sample SPSed at $1800^{\circ} \mathrm{C}$ under an applied pressure of $40 \mathrm{MPa}$. The mechanical properties of ceramics are largely dependent on the mi- crostructure. The liquid phase sintered ceramics have high fracture toughness compared with the solid-phase sintered $\mathrm{SiC}$, because the elongated grains can form during liquid phase sintering [7].

\section{Conclusions}

$\mathrm{SiC}$ ceramics were consolidated by both solid state and liquid phase sintering mechanisms using spark plasma sintering technique. The results of this study showed that relative density of approximately $99 \%$ was obtained for the solid state sintered monolithic $\mathrm{SiC}$ ceramic. Increased sintering temperature and pressure led to an increase in the relative density, Vickers hardness and fracture toughness of the monolithic $\mathrm{SiC}$ ceramics. The use of $\mathrm{Al}_{2} \mathrm{O}_{3}$ as a sintering additive which reacts with the $\mathrm{SiO}_{2}$, forms a liquid phase during the sintering process and the liquid enhances the densification. Hence, the addition of 5 vol. $\% \mathrm{Al}_{2} \mathrm{O}_{3}$ resulted in an increase in relative density and Vickers hardness from $87.2 \%$ to $97.7 \%$ and 10.2 to $26.8 \mathrm{GPa}$, respectively, for the samples SPSed at $1800{ }^{\circ} \mathrm{C}$ under a pressure of $40 \mathrm{MPa}$. Moreover, the addition of 5 vol. $\% \mathrm{Al}_{2} \mathrm{O}_{3}$ decreased the densification temperature and increased the fracture toughness value to $5.8 \pm 0.5 \mathrm{MPa} \mathrm{m}{ }^{1 / 2}$ for the samples SPSed at $1800^{\circ} \mathrm{C}$ under a pressure of $40 \mathrm{MPa}$. Increase in applied pressure did not have a significant effect on the relative density, Vickers hardness and fracture toughness values for the samples containing 5 vol. $\% \mathrm{Al}_{2} \mathrm{O}_{3}$.

\section{Acknowledgments}

This work was supported by the Scientific Research Project Funds of Istanbul Technical University (project number: 34322). Mehtap Deniz Unlu greatly acknowledges the Scientific and Technological Research Council of Turkey for the scholarship she has received during her Ph.D. study at Istanbul Technical University.

\section{References}

[1] G. Magnani, G. Beltrami, G.L. Minoccari, L. Pilotti, J. Eur. Ceram. Soc. 21, 633 (2001).

[2] V.A. Izhevskyi, L.A. Genova, A.H.A. Bressiani, J.C. Bressiani, Int. J. Refract. Met. Hard Mater. 19, 409 (2001).

[3] A. Lara, A.L. Ortiz, A. Munoz, A.D. Rodriguez, Ceram. Int. 38, 45 (2012).

[4] Y. Zhou, K. Hirao, M. Toriyama, J. Mater. Res. 14, 3363 (1999).

[5] A. Can, M. Hermann, D.S. McLachen, I. Sigalas, J. Adler, J. Eur. Ceram. Soc. 26, 1707 (2006).

[6] M. Hermann, R. Neher, K. Brandt, S. Hoehn, J. Eur. Ceram. Soc. 30, 1495 (2010).

[7] M. Hotta, J. Hojo, J. Eur. Ceram. Soc. 30, 2117 (2010). 